\title{
Pengaruh Pakan terhadap Lama Hidup dan Kebugaran Imago Eriborus argenteopilosus Cameron (Hymenoptera: Ichneumonidae)
}

\author{
NOVRI NELLY', DAMAYANTI BUCHORI ${ }^{2)}$ \\ ${ }^{1)}$ Jurusan HPT Fakultas Pertanian Universitas Andalas Padang, \\ Kampus Unand Limau Manis Padang. \\ 2) Departemen Proteksi Tanaman Fakultas Pertanian IPB Bogor, Kampus Dramaga Bogor.
}

(diterima Agustus 2007, disetujui Februari 2008)

\begin{abstract}
The Effect of Feeding on Longevity and Fitness Traits of Adult Eriborus argenteopilosus Cameron (Hymenoptera: Ichneumonidae). Research of the effect of adult feeding to longevity and fecundity of parasitoid Eriborus argenteopilosus Cameron (Hymenoptera: Ichneumonidae) was conducted under laboratory conditions. Fitness was studied by feeding adults Eriborus with different types of food ( $10 \%$ honey, $10 \%$ yeast, aquadest). Results of the research indicated that fitness and longevity were highest when Eriborus was fed with $10 \%$ honey. There is a positive correlation between size and fecundity, suggesting certain measures of body length can be used as indicators of fitness.
\end{abstract}

KEY WORDS: feeding, life time, fitness, parasitoid Eriborus argenteopilosus

\section{PENDAHULUAN}

Parasitoid E. argenteopilosus merupakan agens hayati yang sangat potensial untuk dikembangkan sebagai agens pengendali Crocidolomia pavonana karena hampir selalu ditemui di pertanaman sayuran (Nelly \& Yaherwandi 2006). Eriborus argenteopilosus (Cameron) adalah parasitoid yang bersifat koinobiont. Beberapa penelitian menunjukkan bahwa rentang kisaran inang bagi $E$. argenteopilosus ini cukup luas, yaitu antara lain Crocidolomia pavonana Fab. (Lepidoptera: Crambidae),
Spodoptera litura (Lepidoptera: Noctuidae), dan Heliothis armigera (Lepidoptera: Noctuidae) (Kalshoven, 1981 ).

Pada umumnya parasitoid betina lebih menyukai instar awal sebagai tempat peletakan telurnya. Pada larva C. pavonana parasitoid betina telah diketahui untuk memilih meletakkan telurnya pada instar 1, 2 dan 3 . Implikasi dari pemilihan inang yng berbeda ukuran ini adalah pada kebugaran parasitoid yang muncul. Berbagai penelitian telah menunjukkan bahwa ukuran inang berpengaruh terhadap kebugaran parasitoid, yaitu dari inang yang berukuran lebih besar 
parasitoid yang dihasilkan juga berukuran lebih besar dibanding inang yang kecil (Nelly 2005).

Kebugaran parasitoid juga dipengaruhi oleh ketersediaan sumber pakan, jenis pakan dan frekuensi mendapatkannya. Kondisi ini sangat mempengaruhi kehidupan imago parasitoid antara lain lama hidup dan keperidian. Hasil penelitian Fadamiro \& Heimpell (2001) pada imago betina parasitoid Macrocentrus grandii (Hymenoptera: Braconidae) yang diberi pakan tiap hari memiliki lama hidup lebih panjang (14 sampai 21 hari), dibandingkan dengan yang diberi pakan sekali 2 hari ( 9 - 16 hari). Jenis pakan berupa gula untuk parasitoid betina Cotesia rubecula (Marshall) (Hymenoptera: Braconidae), dapat meningkatkan lama hidup dan waktu peletakan telurnya (Sieckmann et al. 2001). Parasitoid Telenomus minutum yang diberi pakan yeast atau air saja tidak berbeda nyata dalam hal lama hidup imago betinanya (2,6 hari). Sedangkan apabila diberi madu dapat meningkatkan lama hidupnya sampai sepuluh kali (26,4 hari) (Leatemia et al. 1995). Akan tetapi lama hidup dan keperidian imago betina parasitoid tidak dipengaruhi oleh ukuran tubuhnya (Coombs 1997).

Dalam kehidupan parasitoid, selain keadaan lingkungan, ketersediaan pakan juga akan mempengaruhi kebugarannya. Menurut Quicke (1997), yang merupakan faktor kebugaran parasitoid adalah siklus hidup, sintasan, keperidian, dan daya parasitisasinya. Walaupun demikian, inang yang lebih besar memiliki kemampuan mengelak yang juga cukup besar. Semua faktor ini pada akhirnya akan mempengaruhi pemilihan parasitoid terhadap inangnya.

\section{BAHAN DAN METODE}

\section{Pengaruh Pakan terhadap}

Keperidian dan Lama Hidup Imago Betina $E$. argenteopilosus

Penelitian dilakukan di laboratorium Bioekologi Predator dan Parasitoid Departemen Proteksi Tanaman Fakultas Pertanian IPB. Imago betina yang digunakan pada percobaan ini berasal dari hasil pemeliharaan pradewasa pada suhu 20 ${ }^{\circ} \mathrm{C}$ di laboratorium. Rancangan yang digunakan adalah Rancangan Acak Lengkap (RAL) dengan 3 perlakuan pakan bagi imago yaitu: madu $10 \%$, yeast $10 \%$ dan akuades dengan ulangan 10 kali.

Masing-masing imago betina $E$. argenteopilosus dimasukan ke dalam kurungan (tinggi $27 \mathrm{~cm}$ dan diameter $12 \mathrm{~cm}$ ) dan diberi satu ekor imago jantan untuk berkopulasi. Pada kurungan yang berisi satu pasang parasitoid diberi pakan sesuai perlakuan dengan cara menyerapkannya pada kapas, dan diletakkan pada tutup bagian atas kurungan yang terbuat dari kain kasa. Selanjutnya ke 
dalam kurungan tersebut dipaparkan 30 larva $C$. pavonana instar 2 sebagai inang selama 24 jam untuk mengamati tingkat parasitisasinya. Pemaparan inang dilakukan setiap hari sampai imago betina mati, setelah itu dihitung sisa telur dalam ovarinya.

Pengamatan dilakukan terhadap

1). jumlah telur yang diletakkan: Jumlah telur yang diletakkan parasitoid dihitung setiap hari setelah pemaparan larva inang dengan cara membedah larva inang tersebut dan diamati di bawah mikroskop binokuler.

2. Lama hidup imago betina (hari): dihitung mulai dari imago muncul sampai mati.

3. Sisa telur dalam ovari: dihitung setelah imago betina parasitoid mati dengan pembedahan ovarinya.

4. Keperidian potensial (butir): adalah jumlah telur yang diletakkan $E$. argenteopilosus selama masa hidupnya dan sisa telur dalam ovari setelah parasitoid mati.

\section{Korelasi antara Ukuran Morfologi dan Keperidian Imago $E$. argenteopilosus.}

Pengukuran morfologi dilakukan terhadap semua imago betina yang diberi pakan berbeda. Imago betina yang sudah mati, dipisah-pisah bagian tubuh yaitu sayap depan dan belakang, tungkai dan kepala. Masing masing bagian tubuh kemudian difoto dengan kamera digital Nikon dan diukur dengan program tps dig (Rohlf 2004).
Bagian yang diukur yaitu panjang sayap depan, panjang sayap belakang, lebar sayap depan dan sayap belakang, panjang tibia dan lebar kepala. Pengukuran mengacu kepada metode Bennet \& Hoffmann (1998) sebagai berikut, lebar kepala diukur dari mulai sisi kanan atau sebaliknya melintasi mata, sedangkan panjang sayap diukur dari pangkal sayap sampai ujung sayap. Lebar sayap diukur dari ujung radial pertama (Ri) sampai ujung anal ke 3 (A3). Untuk panjang tibia tungkai belakang diukur dari pangkal femur/tibia sampai pangkal tibia/tarsus. Analisa dilakukan terhadap korelasi antara ukuran dengan keperidian imago betina.

\section{Analisis Data}

Data dianalisis dengan ANOVA menggunakan program STATISTIX 8.0 dan dilanjutkan dengan uji Tukey pada taraf nyata $1 \%$ (Analytical Software for Windows 2003)

\section{HASIL DAN PEMBAHASAN}

\section{Ukuran Morfologi dan Keperidian Imago $E$. argenteopilosus}

Hasil pengamatan terhadap ukuran morfologi imago betina menunjukkan bahwa semua imago relatif berukuran sama $(\mathrm{P}>0,01)$, kecuali panjang sayap (Tabel 1). Tidak berbedanya ukuran tubuh ini penting untuk ditunjukkan karena pada umumnya ukuran berkorelasi positif dengan keperidian (Nelly 2005), sehingga bila imago yang digunakan berbeda ukuran, maka 
Tabel 1. Hasil pengamatan ukuran morfologi imago betina E. argenteopilosus

\begin{tabular}{lccc}
\hline \multirow{2}{*}{ Morfologi } & \multicolumn{3}{c}{ Ukuran morfologi imago (mm) } \\
\cline { 2 - 4 } & Madu10\% & Yeast $10 \%$ & Akuades \\
\hline Panjang sayap depan & $6,03 \pm 0,41 \mathrm{a}$ & $5,72 \pm 0,35 \mathrm{ab}$ & $5,59 \pm 0,44 \mathrm{~b}$ \\
Lebar sayap depan & $2,13 \pm 0,16 \mathrm{a}$ & $2,05 \pm 0,33 \mathrm{a}$ & $2,07 \pm 0,29 \mathrm{a}$ \\
Panjang sayap belakang & $4,38 \pm 0,14 \mathrm{a}$ & $4,10 \pm 0,14 \mathrm{ab}$ & $4,05 \pm 0,48 \mathrm{~b}$ \\
Lebar sayap belakang & $1,29 \pm 0,24 \mathrm{a}$ & $1,20 \pm 0,24 \mathrm{a}$ & $1,42 \pm 0,08 \mathrm{a}$ \\
Panjang tibia & $1,93 \pm 0,11 \mathrm{a}$ & $1,85 \pm 0,11 \mathrm{a}$ & $1,95 \pm 0,31 \mathrm{a}$ \\
Lebar kepala & $1,65 \pm 0,03 \mathrm{a}$ & $1,58 \pm 0,09 \mathrm{a}$ & $1,63 \pm 0,19 \mathrm{a}$ \\
\hline
\end{tabular}

Angka yang diikuti huruf yang sama pada baris yang sama tidak berbeda nyata sesamanya dengan uji Tukey pada taraf nyata $5 \%$

Tabel 2. Hasil pengamatan lama hidup dan keperidian imago betina $E$. argenteopilosus yang diberi pakan berbeda (rerata $\pm \mathrm{sd}$ )

\begin{tabular}{lcccc}
\hline \hline Jenis pakan & $\begin{array}{c}\text { Lama hidup } \\
\text { (hari) }\end{array}$ & $\begin{array}{c}\text { Jumlah telur yang } \\
\text { diletakkan }\end{array}$ & $\begin{array}{c}\text { Sisa telur dalam } \\
\text { ovari (butir) }\end{array}$ & $\begin{array}{c}\text { Keperidian } \\
\text { (butir) }\end{array}$ \\
\hline Madu $10 \%$ & $9,00 \pm 3,00 \mathrm{a}$ & $134,30 \pm 65,58 \mathrm{a}$ & $123,50 \pm 55,38 \mathrm{a}$ & $257,80 \pm 90,30 \mathrm{a}$ \\
Yeast $10 \%$ & $5,70 \pm 2,00 \mathrm{~b}$ & $16,80 \pm 24,80 \mathrm{~b}$ & $95,40 \pm 19,23 \mathrm{a}$ & $112,20 \pm 18,52 \mathrm{~b}$ \\
Akuades & $5,20 \pm 2,18 \mathrm{~b}$ & $33,10 \pm 17,70 \mathrm{~b}$ & $83,80 \pm 29,64 \mathrm{a}$ & $116,90 \pm 44,59 \mathrm{~b}$ \\
\hline
\end{tabular}

Angka yang diikuti oleh huruf yang sama pada kolom yang sama pada masing- masing perlakuan tidak berbeda nyata dengan uji lanjut Tukey pada taraf nyata 5\%

pengaruh pakan tidak akan terlihat jelas, karena adanya pengaruh ukuran tubuh yang juga akan mempengaruhi hasil. Karena hasil analisis statistik menunjukkan bahwa imago yang digunakan relatife berukuran sama, maka semua perbedaan yang muncul tidak ada kaitannya dengan ukuran tubuh.

\section{Pengaruh Pakan terhadap Lama Hidup dan Keperidian Imago Betina E. argenteopilosus}

Hasil pengamatan terhadap lama hidup dan keperidian imago menunjukkan bahwa betina $E$. argenteopilosus dipengaruhi oleh pakan $\left(\mathrm{db}_{\text {perlakuan }}=2, \mathrm{db}\right.$ error $=27, \mathrm{P}=$ 0,000). Sedangkan sisa telur dalam ovari tidak berbeda nyata antara imago E. argenteopilosus yang diberi jenis pakan yang berbeda $\left(\mathrm{db}_{\text {perlakuan }}=2, \mathrm{db}\right.$ error $=27, P=0,014)$ (Tabel 2). Imago betina $E$. argenteopilosus yang diberi pakan madu $10 \%$ lebih lama hidupnya, dan keperidiannya paling tinggi berbeda nyata secara statistik dibandingkan dengan pakan yeast $10 \%$ dan akuades. Jumlah telur yang diletakkan oleh imago betina $E$. argenteopilosus juga lebih banyak jika diberi pakan madu dibandingkan dengan pakan yeast dan akuades. Banyaknya jumlah telur yang diletakkan betina E. argenteopilosus karena lama hidupnya yang panjang 
dan oviposisi dilakukan selama hidupnya.

Hubungan antara ukuran panjang sayap depan dan belakang, lebar sayap depan dan belakang, panjang tibia, dan lebar kepala, dengan keperidian mempunyai nilai $\mathrm{r}^{2}$ yang kecil yaitu 0,002 - 0,078. Hal ini menunjukkan bahwa nilai korelasi hanya $0,2-7,0 \%$ atau bisa dikatakan tidak ada korelasi antara keperidian dan ukuran morfologi $E$. argenteopilosus.

Kecenderungan hubungan antara keperidian dengan morfologi parasitoid adalah positif, artinya semakin besar ukuran morfologi semakin tinggi keperidian, walaupun secara statistik tidak berkorelasi. Garis regresi linear antara ukuran panjang sayap depan dan belakang, lebar sayap depan dan belakang, panjang tibia, dan lebar kepala, dengan keperidian menggambarkan nilai $\mathrm{r}^{2}$ yang kecil yaitu 0,002 - 0,078 (Gambar 1).

Pakan berpengaruh terhadap kebugaran imago betina E. argenteopilosus, yaitu lama hidup dan keperidian. Larutan madu $10 \%$ adalah pakan yang paling baik untuk peningkatan lama hidup dan keperidian dibandingkan dengan yeast $10 \%$ dan akuades saja. Hal ini diduga karena madu mempunyai kandungan gula dan juga bersifat alami karena tanpa diolah, sehingga lebih disukai parasitoid. Kandungan glukosa yang terdapat pada madu mampu memberi energi bagi parasitoid sehingga mampu memperpanjang lama hidupnya. Lama hidup yang panjang akan menghasilkan jumlah telur yang juga lebih banyak jika dibandingkan dengan yang lama hidupnya pendek. Hal ini sejalan dengan hasil penelitian Nelly (2005) bahwa oviposisi oleh imago betina $E$. argenteopilosus dilakukan selama masa hidupnya. Semakin lama masa hidup imago betina semakin banyak jumlah telur yang diletakkannya.

Menurut Almaeda et al. (2002) parasitoid yang diberi pakan larutan madu, lama hidupnya dua atau tiga kali lebih lama dibandingkan dengan hanya diberi akuades. Madar \& Miller (1983) mengamati lama hidup imago Apanteles yakutatensis (Hymenoptera: Braconidae) endoparasitoid larva Autographa calfornic (Spayer) (Lepidoptera: Noctuidae), terlihat peningkatan lama hidup yang nyata bila imago parasitoid diberi larutan gula sebagai pakannya dibandingkan tidak diberi pakan sama sekali.

Imago betina $E$. argenteopilosus tetap bisa mempertahankan hidupnya apabila diberi pakan yeast $10 \%$ dan akuades, akan tetapi jumlah telur yang dihasilkan lebih sedikit jika dibandingkan dengan yang diberi pakan madu $10 \%$. Sedikitnya jumlah telur yang dihasilkan parasitoid apabila diberi akuades dan yeast diduga karena tidak terpenuhi energi yang dibutuh- 
a)

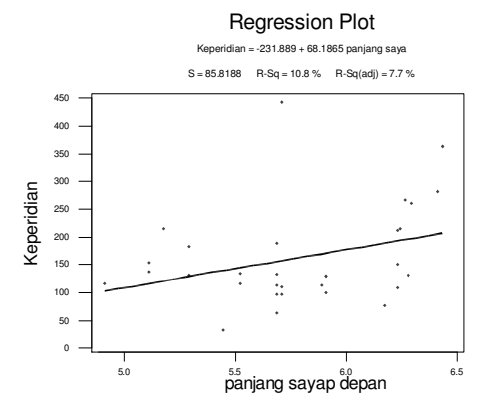

b)

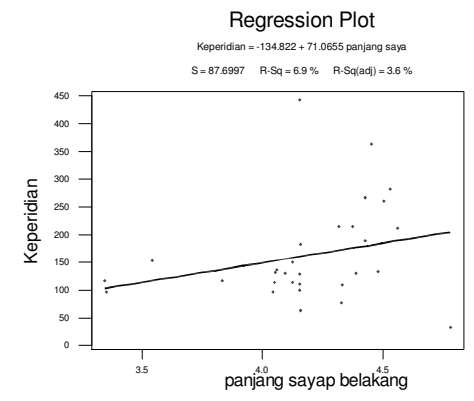

c)

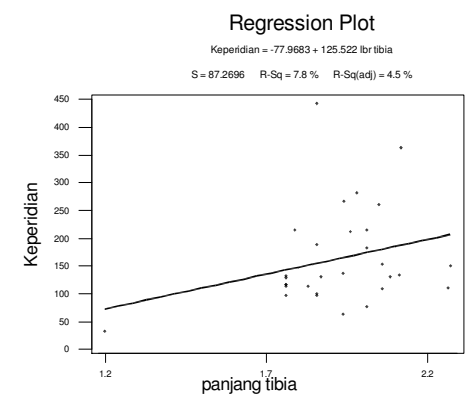

d)

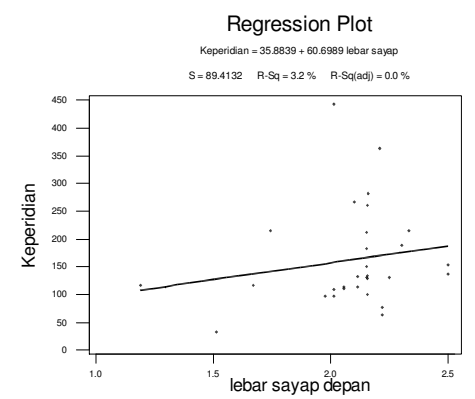

e)

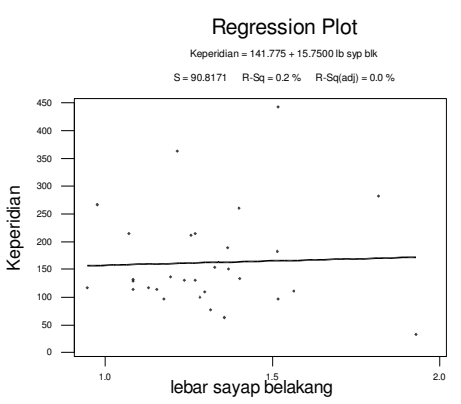

f)

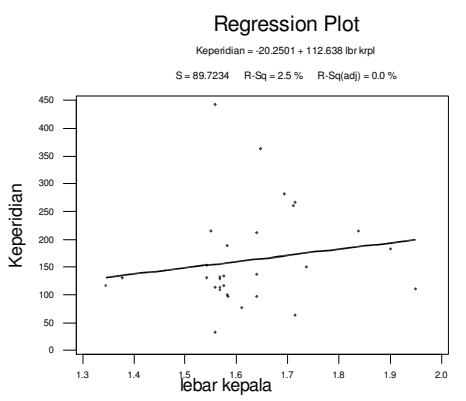

Gambar 1. Hubungan antara keperidian dengan ukuran morfologi imago parasitoid E. argenteopilosus [a) panjang sayap depan, b) panjang sayap belakang, c) panjang tibia, d) lebar sayap depan, e) lebar sayap belakang, f) lebar kepala]

kannya. Parasitoid memerlukan energi madu terdapat sucrosa dan fructosa untuk memproduksi telur dan yang dapat dijadikan sumber energi melakukan oviposisi. Imago betina $E$. bagi parasitoid. Selanjutnya Fadamiro argenteopilosus dapat memperoleh \& Hampell (2001), menyatakan energi dari madu yang dikonsumsinya. sumber energi utama bagi imago Menurut Leatemia et al. (1995) pada parasitoid adalah gula, yang 
dilapangan diambil dari nektar atau madu. Masa hidup imago parasitoid dapat diperlama sampai sepuluh kali di laboratorium jika diberi pakan gula. Hasil penelitian Tisdale dan Sapping (2001) pada imago Spodoptera exigua Hub. yang diberi pakan berbeda juga menunjukkan tingkat keperidian yang tinggi dan lama hidup yang lebih panjang apabila diberi pakan madu $10 \%$ dibandingkan dengan hanya diberi akuades saja.

Pemberian yeast sebagai pakan imago ternyata tidak meningkatkan keperidian dan lama hidup betina Larutan yeast yang diharapkan dapat memberi sumber protein kepada imago betina parasitoid ternyata tidak memberikan pengaruh kepada keperidian dan lama hidupnya. Sama halnya dengan hasil penelitian Leatemia et al. (1995) yang menyatakan bahwa pemberian yeast sebagai sumber protein kepada dewasa T. minutum tidak meningkatkan keperidian dan lama hidup parasitoid ini. Imago betina $T$. minutum jika diberi pakan yeast $20 \%$ menyebabkan lama hidupnya 2,5 hari dan 2,6 hari jika diberi yeast $50 \%$, tidak berbeda nyata dengan imago yang diberi pakan akuades (2,4 hari). Sedangkan jika imago parasitoid ini diberi pakan madu $50 \%$ menyebabkan lama hidupnya 25,7 hari. Pemberian protein untuk kehidupan imago betina disarankan pada pakan pradewasa.
Ukuran morfologi imago secara statistik tidak berkorelasi dengan keperidian, tetapi kecenderungan yang terlihat adalah semakin besar ukuran morfologi semakin tinggi keperidiannya. Sesuai dengan hasil penelitian Lauziere et al. (2000), tidak ada pengaruh ukuran tubuh parasitoid Cephalonomia stephanoderis Betrem (Hymenopetra: Bethylidae) terhadap lama hidup, akan tetapi ada kecendrungan semakin besar ukuran semakin tinggi keperidiannya. Selanjutnya hasil penelitian Coombs (1997) juga menyatakan bahwa pakan berpengaruh terhadap lama hidup Trichopoda giacomellii parasitoid dari Nezara viridula dan lama hidup berpengaruh terhadap keperidian parasitoid ini. Lama hidup dan keperidian $T$. giacomellii tidak berkorelasi dengan ukuran tubuhnya.

\section{KESIMPULAN}

Pakan berpengaruh terhadap keperidian dan lama hidup imago. Pemberian madu 10\% menyebabkan lama hidup imago 9,0 hari, lebih lama dibandingkan imago dengan pakan yeast $10 \%$ dan aquades yaitu 5,7 hari dan hanya 5,2 hari bila diberi akuades. Demikian juga dengan keperidian, imago yang diberi pakan madu jumlah total telur yang dihasilkan adalah 257,8 butir, lebih tinggi dibandingkan bila diberi yeast (112,2 butir) dan diberi aquades (116,9 butir). 


\section{DAFTAR PUSTAKA}

Almeida MAFD, Prado APD, Geden CJ. 2002. Influence temperature on development time and longevity of Tachinaephagus zealandicus (Hymenoptera: Encyrtidae), and effects of nutrition and emergence order on longevity. Environ.Entomol. 31(2):375 380.

Analytical Software for Windows 2003. Statistic 8.0 for Windows. Florida Analytical Software Publisher.

Bennet DM, Hoffmann AA. 1998. Effect of size and fluctuating asymetris on field fitness of parasitoid Trichogramma curverae (Hymenoptera: Trichogramatidae). J. Animal Ecol. 67:580-591.

Coombs MT. 1997. Influence of adult food deprivation and body size on fecundity longevity of Trichopoda giacomellii: a South American parasitoid of Nezara viridula. Biological Control: 8, 119 - 123.

Fadamiro HY, Heimpel GE. 2001. Effects of partial sugar deprivation on lifespan and carbohydrate mobilization in the Parasitoid Macrocentrus grandii (Hymenoptera: Braconidae). Ann. Entomol. Soc. Am. 94 (6): 909 -916.

Leatemia JA, Laing JE, Corrigan JE. 1995. Effect of adult nutrition on longeviry, fecundity, and offspring sex ratio of Trichogramma minutum iley (Hymenoptera:

Trichogrammatidae). The

\section{Canadian Entomologist} 127:245-254.

Kalshoven LGE. 1981. The Pests of Crops in Indonesia. Revised and Translated by P.A.van der Laan. PT. Ichtiar Baru-van Hoeve, Jakarta

Madar RJ, Miller JC. 1983. Developmental biology of Apanteles yakutatensis (Hymenoptera: Brachonidae), a primary parasite of Autogrpha californica (Lepidoptera: Noctuidae) Ann. Entomol. Soc. Am. 76: 683 - 687.

Nelly N. 2005. Dinamika Interaksi Parasitoid Eriborus argenteopilosus Cameron (Hymenoptera:

Ichneumonidae) dengan Inangnya pada Suhu dan Kondisi Fisiologis Berbeda. [Disertasi]. Pascasarjana Univ Andalas.

Nelly N, Yaherwandi. 2006. Struktur Populasi Eriborus argenteopilosus Cameron (Hymenoptera: Ichneumonidae) Parasitoid Crocidolomia pavonana Fabricius (Lepidoptera: Pyralidae) Pada Beberapa Tipe Lansekap: Implikasinya Terhadap Keefektifan Parasitoid Sebagai Agens Pengendalian Hayati di Lapangan. Laporan penelitian Hibah Bersaing XIII, DP2M Dikti tahun 2005-2006

Quicke DLJ. 1997. Parasitic Wasp; Chapman and Hall. London.

Rohlf FJ. 2004. tps Utill, file utility program Version 1.26. Department of Ecology an 
evolution, State University of New York at Stony Brook.

Sickmann G, Tenhumbrg B, Keller M A. 2001. Feeding and Survival in Parasitic Wasp: Sugar Concentration: Sugar concentration and Timing Matter. Oikos 95 95: 425 430.
Tisdale RA, Sappington TW. 2001. Realized and potencial fecundity, egg fertility, and longevity of laboratory - reread female beet armyworm (Lepidoptera: Noctuidae) under different adul diet regimes. Ann. Entomol.Soc. Am. 94 (3): 415-419. 